\title{
HEPATITIS B AND C VIRUS INFECTION AMONG HEALTH CARE WORKERS IN GENERAL SURGERY DEPARTMENT, ASSIUT UNIVERS ITY HOSPITALS
}

\author{
By \\ ${ }^{1}$ Zayet HH, ${ }^{2}$ Ezz El-Din AM, ${ }^{3} \mathrm{Ahmed} \mathrm{SM}$ and ${ }^{3} \mathrm{El}$-Khayat MR \\ ${ }^{1}$ Department of Occupational and Environmental Medicine, Cairo University - ${ }^{2}$ Departments of Clinical \\ Pathology and ${ }^{3}$ Public Health and Community Medicine, Assiut University.
}

\begin{abstract}
:
Introduction: Approximately $30 \%$ of the world's population has serologic evidence of current or past HBV infection. Middle East has an intermediate level of HBV endemicity (2-7\%).It is estimated that $3 \%$ of the global population have chronic HCV infection. The prevalence of Anti-HCV in Egypt was $14 \%$ in 2010. More than 30 dangerous blood-borne pathogens are transmitted by contaminated needles, but those of primary significance to healthcare workers (HCWs) are hepatitis B virus, hepatitis $\mathrm{C}$ virus and human immunodeficiency virus. Needle stick and sharps injuries (NSSIs) have been recognized as one of the most serious occupational hazards among HCWs. Aim of Work: To study the frequency and risk factors of hepatitis B \& C virus infection among health care workers in general surgery department, Assiut University Hospitals. Materials and Methods: A Cross-sectional study was carried out among HCWs in general surgery department, Assiut University Hospitals. This study included 215 HCWs, of them 21 refused to be subjected to serological examination. The instrument used was a structured interview questionnaire. Blood samples were taken from HCWs to screen for Anti-HCV, HBsAg, anti-HBc and anti-HBs. Results: $5.2 \%$ of HCWs were Anti $\mathrm{HCV}$ positive, $3.1 \%$ were $\mathrm{HBs} \mathrm{Ag}$ positive, $28.9 \%$ were Anti $\mathrm{HBc}$ positive, 55.7\% were Anti HBs positive and $32.5 \%$ of HCWs were negative. Hepatitis virus infection was statistically significant among older age group, nurses and technicians and with long working duration. Conclusion and Recommendations: to improve hepatitis B vaccination coverage among HCWs, avoid needle stick and sharps injuries (NSSIs) and to improve the reporting system.
\end{abstract}

Key words: Viral Hepatitis, Health Care Workers, General Surgery, Anti-HCV, HBsAg, anti-HBc and anti-HBs. 


\section{Introduction}

Approximately $30 \%$ of the world's population, or about 2 billion persons, have serologic evidence of current or past HBV infection. WHO estimates that around 4.3 million persons are infected with HBV in the Eastern Mediterranean Region each year (WHO, 2009). Middle East has an intermediate level of HBVendemicity (2- 7\%) (Da Villa and Sepe, 1999).

It is estimated that $3 \%$ of the global population (approximately 170 million people) have chronic $\mathrm{HCV}$ infection and that 3-4 million people are newly infected each year. WHO estimates that around 800000 persons are infected with $\mathrm{HCV}$ in the Eastern Mediterranean Region each year (WHO, 2009). The prevalence of Anti-HCV in Egypt was $14 \%$, about 11826360 persons infected with HCV in 2010 (Lavanchy et al., 2011). Another study reported that the prevalence of antibodies against $\mathrm{HCV}$ in various regions in Egypt ranged from 6 to $28 \%$ (mean $22 \%$ ) (Lauer and Walker, 2001). Anti-HCV seroprevalence rates among blood donors were $0.5 \%$, while higher rates had been observed among hemodialysis patients (20\%) and hemophilia patients $(60 \%$ to 90\%) (Alter and Mast, 1994).
More than 30 dangerous bloodborne pathogens are transmitted by contaminated needles, but those of primary significance to $\mathrm{HCW}$ are hepatitis B virus (HBV), hepatitis $\mathrm{C}$ virus (HCV) and human immunodeficiency virus (HIV) (Kebede and Molla, 2012). World Health Organization estimated that of 35 million $\mathrm{HCW}$ s worldwide, approximately 3 million experienced percutaneous injuries each year and of those injured $70,000,15,000$ and 500 respectively were likely to be infected with HBV, HCV and HIV (WHO, 2003).

Although the majority of these occupational infections occur in developing countries where the prevalence rates of blood borne pathogens and risk of occupational injuries are high (Varghese et al., 2003). Further, the exposure and health impacts are rarely monitored and much remains to be done to protect HCWs from such risks that cause infections, illness, disability and death. These injuries may also impact the quality of health care (Kebede and Molla, 2012).

Needle stick and sharps injuries (NSSIs) have been recognized as one of the most serious occupational hazards 
among healthcare workers (HCWs) (Ciesielski and Metler, 2003). Surgeons have been shown to have a four- to eight fold higher incidence of exposure to patient blood compared with internist (Kebede and Molla, 2012). The risk of exposure is greater with increasing volume of blood loss and prolonged length of procedure (Gutmann et al., 1999).

\section{Aim of Work}

To study frequency and risk factors of hepatitis B \& C virus infection among health care workers in general surgery department, Assiut University Hospitals.

\section{Materials and Methods}

Study site and time: The study was conducted in general surgery department, Assiut University Hospitals between June 2013\& December 2013.

Study design: A cross-sectional study was carried out among the target population.

Study population: Total coverage of assistant lecturers, residents, nurses and workers (215 HCWs) in general surgery department, Assiut University Hospitals. Of them 21 refused to be subjected to serological examination.
Study Methods::

1. Astructured interview questionnaire. The data included in the questionnaire were:

- Socio-demographic data: age, sex, occupation and number of working years.

- History of previous needle injury (how many, circumstances, where, when \& gloves used during injury, reporting \& causes of underreporting).

- History of previous body fluid exposure (type, amount, area of exposure)

- Risk factors (previous blood transfusion, previous complaint of jaundice, presence of infected partner and vaccination against hepatitis B virus).

- Practicing of infection control (e.g. personal protective equipments used, hand washing and re-capping).

2. Laboratory Investigations

Specimen collection: $3 \mathrm{ml}$ of blood samples were taken from 194 HCWs \&serological investigations were done for $\mathrm{HBV} \& \mathrm{HCV}$ using 
chemoleucent- Assay to screen for t-test and chi square test. P-value Anti-HCV antibodies, HBV surface considered significant if less than 0.05. antigen (HBsAg), antibody to hepatitis $B$ core antigen (anti-HBc) \& antibody to hepatitis B surface antigen (antiHBs), in top secrecy by using codes.

Pilot study: a pilot study was carried out on $10 \mathrm{HCWs}$ before starting final data collection.

Data Management: Data analysis was done by using SPSS program version 16. Statistical methods were applied including: descriptive statistics,

\section{Consent:}

Informed consent obtained from those who accepted to participate in the study.

\section{Ethical Approval:}

Reviewing the proposal was carried out before starting data collection via the Ethical Review Committee of Assiut Faculty of Medicine. The aim of the study was explained to each participant before filling the questionnaire. 


\section{Results}

Table (1): Demographic characteristics of healthcare workers (HCWs) included in the study in general surgery department, Assiut University Hospitals, 2013

\begin{tabular}{|c|c|}
\hline Characteristics & Frequency (\%) \\
\hline $\begin{array}{l}\text { Gender: } \\
\text { - } \quad \text { Male } \\
\bullet \quad \text { Female }\end{array}$ & $\begin{array}{r}121(56.3) \\
94(43.7)\end{array}$ \\
\hline $\begin{array}{l}\text { Age(in years): } \\
20-<30 \\
30-<40 \\
-\quad \geq 40 \\
\text { Mean } \pm \text { SD }\end{array}$ & $\begin{array}{c}106(49.5) \\
57(26.5) \\
52(24.0) \\
33.19 \pm(10.025)\end{array}$ \\
\hline $\begin{array}{l}\text { Occupation: } \\
\text { - } \quad \text { Physicians } \\
\text { - } \quad \text { Nurses/ technicians } \\
\text { - } \quad \text { Workers }\end{array}$ & $\begin{array}{c}56(26.0) \\
114(53.0) \\
45(21.0)\end{array}$ \\
\hline 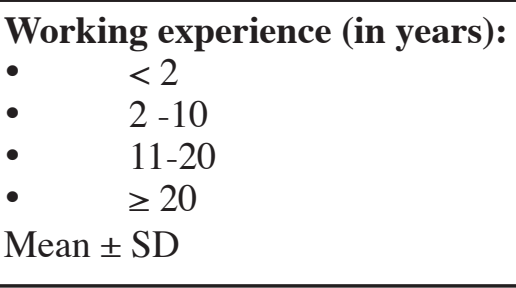 & $\begin{array}{l}26(12.0) \\
93(43.5) \\
50(23.5) \\
46(21.0) \\
10.3 \pm 8.4\end{array}$ \\
\hline Total & $215(100.0)$ \\
\hline
\end{tabular}

Table (1) showed that males constituted $56.3 \%$ of participants. The mean age was about 33 years. About one quarter (26\%) of them were physicians, more than one half $(53 \%)$ were nurses and technicians and about one fifth $(21 \%)$ were workers. 
Table (2): Results of serological investigations and their interpretation for HCWs included in the study in general surgery department, Assiut University Hospitals, 2013.

\begin{tabular}{|c|c|}
\hline Characteristics & Frequency $(\%)$ \\
\hline Negative: (Anti-HCV-ve, HBs-Ag -ve,Anti-HBc -ve, Anti-HBs -ve) & $63(32.5)$ \\
\hline Vaccinated: (Anti-HCV-ve, HBs-Ag -ve, Anti-HBc -ve, Anti-HBs +ve) & $69(35.6)$ \\
\hline HBV+ve: (Anti-HCV-ve, HBs-Ag +ve, Anti-HBc +ve, Anti-HBs -ve) & $6(3.1)$ \\
\hline $\begin{array}{l}\text { Previous HBV: (Anti-HCV-ve, HBs-Ag - ve, Anti-HBc +ve, Anti-HBs } \\
\text { +ve) }\end{array}$ & $33(17.0)$ \\
\hline $\begin{array}{l}\text { Occult HBV(window phase): (Anti-HCV -ve, HBs-Ag -ve, Anti-HBc } \\
\text { +ve, Anti-HBs - ve) }\end{array}$ & $13(6.7)$ \\
\hline HCV +ve: (Anti-HCV+ve, HBs-Ag -ve, Anti-HBc-ve, Anti-HBs -ve) & $2(1.0)$ \\
\hline $\begin{array}{l}\text { HCV+occultHBV: Anti-HCV+ve, HBs-Ag-ve, Anti-HBc +ve, Anti-HBs } \\
\text {-ve) }\end{array}$ & $2(1.0)$ \\
\hline $\begin{array}{l}\text { HCV+previous HBV: Anti-HCV+ve, HBs-Ag-ve, Anti-HBc +ve, Anti- } \\
\text { HBs +ve) }\end{array}$ & $2(1.0)$ \\
\hline $\begin{array}{l}\text { HCV + vaccinated: Anti-HCV+ve, } \mathrm{HBs}-\mathrm{Ag}-\mathrm{ve}, \text { Anti-HBc - ve, Anti-HBs } \\
\text { +ve) }\end{array}$ & $4(2.1)$ \\
\hline Anti-HCV: (HCV-infected) & $10(5.2)$ \\
\hline HBs-Ag: (HBV-infected) & $6(3.1)$ \\
\hline Anti-HBc: (window phase) & $56(28.9)$ \\
\hline Anti-HBs: & $108(55.7)$ \\
\hline
\end{tabular}

Table (2) showed results of serological investigation and their interpretation. $32.5 \%$ of $\mathrm{HCW}$ s were negative, $35.6 \%$ were Anti HBs positive (vaccinated), 3.1\% were $\mathrm{HBs} \mathrm{Ag}$ positive, $17 \%$ had previous $\mathrm{HB}$ virus infection (anti $\mathrm{HBc}$ and anti $\mathrm{HBs}+\mathrm{ve}$ ), $6.7 \%$ had occult $\mathrm{HBV}$ (window phase)(anti $\mathrm{HBc}+\mathrm{ve}$ ) and $2.1 \%$ of HCWs were $\mathrm{HCV}$ positive. Collectively, it was found that $5.2 \%$ of $\mathrm{HCW}$ sere Anti HCV positive, $3.1 \%$ were $\mathrm{HBs} \mathrm{Ag}$ positive, $28.9 \%$ were Anti $\mathrm{HBc}$ positive and $55.7 \%$ were Anti HBs positive. 
Table (3): Exposure to Needle Stick and Sharps Injuries (NSSIs) among HCWs included in the study in general surgery department, Assiut University Hospitals, 2013.

\begin{tabular}{|c|c|}
\hline Characteristics & Frequency $(\%)$ \\
\hline $\begin{array}{l}\text { Exposure history to NSSIs: } \mathrm{N}=215 \\
\text { - } \quad \text { Exposed } \\
\text { - Not exposed }\end{array}$ & $\begin{array}{c}186(86.5) \\
29(13.5)\end{array}$ \\
\hline $\begin{array}{l}\text { Where injury occur: } \mathrm{N}=186 \\
\text { - } \quad \text { Patient rooms } \\
\text { - } \quad \text { Operation rooms } \\
\text { - Others (e.g Emergency department, Intensive care } \\
\quad \text { unit(ICU) \& clinic) }\end{array}$ & $\begin{array}{l}100(53.8) \\
54(29.0) \\
32(17.2)\end{array}$ \\
\hline $\begin{array}{l}\text { Source of injury: } \mathrm{N}=186 \\
\text { - Known } \\
\text { - Not known }\end{array}$ & $\begin{array}{l}90(48.4) \\
96(51.6)\end{array}$ \\
\hline $\begin{array}{l}\text { Hepatitis serology among source patient: } \mathrm{N}=90 \\
\text { - } \mathrm{HCV}+\mathrm{ve} \\
\text { - } \mathrm{HBV}+\mathrm{ve} \\
\text { - } \quad \text { Combined HCV \& HBV } \\
\text { - } \quad \text { Negative } \\
\text { - } \\
\end{array}$ & $\begin{aligned} 25 & (27.8) \\
2 & (2.2) \\
3 & (3.3) \\
19 & (21.1) \\
41 & (45.6)\end{aligned}$ \\
\hline $\begin{array}{l}\text { Injury circumstances: } \mathrm{N}=186 \\
\text { - } \quad \text { Before use } \\
\text { - } \quad \text { During use } \\
\text { - } \quad \text { Ruring disposal } \\
\end{array}$ & $\begin{array}{c}6(3.2) \\
80(43.0) \\
49(26.3) \\
51(27.5) \\
\end{array}$ \\
\hline $\begin{array}{l}\text { Tools causing injury: } \mathrm{N}=186 \\
\text { - } \quad \text { Hollow bore needle } \\
\text { - } \quad \text { Surgical tool (e.g. Suture needle) } \\
\text { - } \quad \text { Others (e.g lancet \& glass) }\end{array}$ & $\begin{array}{c}115(61.9) \\
63(33.8) \\
8(4.3)\end{array}$ \\
\hline $\begin{array}{l}\text { Reporting: } \\
\text { Res } \\
\text { - } \quad \text { Yes } \\
\quad \text { No }\end{array}$ & $\begin{array}{c}8(4.3) \\
178(95.7)\end{array}$ \\
\hline $\begin{array}{l}\text { Causes of non-reporting: } \mathrm{N}=178 \\
\text { - } \quad \text { Not a health risk } \\
\text { - } \quad \text { No trust in infection control unit (ICU) } \\
\text { - } \quad \text { Fear of infection }\end{array}$ & $\begin{array}{l}75(42.1) \\
63(3504) \\
40(22.5)\end{array}$ \\
\hline
\end{tabular}


Table (3) showed that $86.5 \%$ of HCWs were exposed to needle stick sharps injuries (NSSIs). Most of NSSIs occurred in patient rooms (53.8\%) or in operation rooms $(29 \%)$. The patient source of injury was known in $48.4 \%$ of cases. $27.8 \%$ of known sources of injury were hepatitis $\mathrm{C}$ positive, $2.2 \%$ were hepatitis B positive and $21 \%$ were negative. Most of NSSIs occurred during use (43\%) or during recapping of tools causing injury (26.3\%). Most tools causing injuries were hollow bore needles (61.9\%) and surgical tools (e.g. suture needles) (33.8\%). Only 4.3\% of injured individuals reported their injuries. The causes of non-reporting were no trust in infection control unit $(35.4 \%)$ or because they considered these injuries as not a health risk $(42.1 \%)$. 
Table (4): Exposure to blood or body fluids among HCWs included in the study in general surgery department, Assiut University Hospitals, 2013.

\begin{tabular}{|c|c|}
\hline Characteristics & Frequency $(\%)$ \\
\hline $\begin{array}{l}\text { Exposure history } \\
\text { - } \quad \text { Exposed } \\
\text { - } \quad \text { Not exposed }\end{array}$ & $\begin{array}{c}146(68.0) \\
69(32.0)\end{array}$ \\
\hline $\begin{array}{l}\text { Type of body fluids involved in the exposure:* N146= } \\
\text { - } \quad \text { Blood or blood products } \\
\text { - } \quad \text { Vomit } \\
\text { - } \quad \text { Peritoneal fluid } \\
\text { - } \quad \text { Others (e.g Sputum, pleural fluids, saliva) }\end{array}$ & $\begin{array}{l}115(79.0) \\
42(30.0) \\
33(22.5) \\
33(22.5) \\
34(23.5)\end{array}$ \\
\hline $\begin{array}{l}\text { The exposed part:* } \\
\text { - } \quad \text { Intact skin } \\
\text { - } \quad \text { Covered area } \\
\text { - } \quad \text { Eyes (conjunctiva) } \\
\text { - } \quad \text { Non-intact skin } \\
\text { - } \quad \text { Others(nose\& mouth) } \\
\end{array}$ & $\begin{array}{l}101(69.0) \\
50(34.0) \\
19(13.0) \\
14(9.5) \\
9(6.5) \\
\end{array}$ \\
\hline $\begin{array}{ll}\text { Site of exposure:\# } \\
\text { - } & \text { Hands } \\
\text { - } & \text { Chest } \\
\text { - } & \text { Face } \\
\text { - } & \text { Upper limb } \\
\text { - } & \text { Lower limb }\end{array}$ & $\begin{array}{l}111(76.0) \\
31(21.0) \\
29(20.0) \\
16(11.0) \\
7(5.0)\end{array}$ \\
\hline $\begin{array}{ll}\text { Cause of exposure to blood and body fluid: } \\
\text { - } & \text { Direct patient contact } \\
\text { - } & \text { Specimen container leaked/spilled/broken } \\
\text { - } & \text { Slipped canula } \\
\text { - } & \text { Others (e.g. Ryle insertion) } \\
\end{array}$ & $\begin{array}{c}72(49.3) \\
32(21.9) \\
28(19.1) \\
14(9.5) \\
\end{array}$ \\
\hline $\begin{array}{l}\text { Action after exposure:* } \\
\text { - Wash hands with water \& alcohol } \\
\text { - } \quad \text { Make investigation } \\
\text { - } \quad \text { Didn't do any thing } \\
\end{array}$ & $\begin{array}{c}132(90.5) \\
10(6.8) \\
12(8.2) \\
\end{array}$ \\
\hline $\begin{array}{l}\text { Vaccination: } \\
\text { - } \quad \text { Yes } \\
\text { - } \quad \text { No }\end{array}$ & $\begin{array}{c}132(61.4) \\
83(38.6)\end{array}$ \\
\hline $\begin{array}{l}\text { Doses of hepatitis B vaccine received: } \\
\text { - } \quad \text { One dose } \\
\text { - } \quad \text { Two doses } \\
\text { - } \quad \geq \text { Three doses }\end{array}$ & $\begin{array}{l}23(17.4) \\
27(20.5) \\
82(62.1)\end{array}$ \\
\hline
\end{tabular}

\# There may be more than one answer. 
Table (4) showed that about two thirds of HCWs (68\%) were exposed to blood or body fluids. Most of these fluids were blood or blood products (79\%), vomit $(30 \%)$, peritoneal fluids and urine (22.5\% for each). The exposed part were most commonly skin (69\%) or covered area (43\%). The most common site exposed were hands $(76 \%)$ or chest $(21 \%)$ or face $(20 \%)$. 
Table (5): Relationship between infection and characteristics of HCWs included in the study in general surgery department, Assiut University Hospitals, 2013.

\begin{tabular}{|c|c|c|c|}
\hline Characteristic & $\begin{array}{c}\text { Infected } \\
\text { No. }(\mathrm{R} \%)\end{array}$ & $\begin{array}{c}\text { Non-Infected } \\
\text { No. }(\mathrm{R} \%)\end{array}$ & P-value \\
\hline $\begin{array}{ll}\text { Sex: } & \mathrm{N}=194 \\
\text { - } & \text { Male } \\
\text { - } & \text { Female }\end{array}$ & $\begin{array}{l}36(33.0) \\
26(30.6)\end{array}$ & $\begin{array}{c}73(67.0) \\
59(69.4)\end{array}$ & 0.718 \\
\hline Mean age $( \pm \mathrm{SD})$ & $39.1 \pm(12.2)$ & $30.5 \pm(8.0)$ & $0.001 *$ \\
\hline $\begin{array}{ll}\text { Occupation: } \mathrm{N}=194 \\
\text { - } & \text { Physicians } \\
\text { - } & \text { Nurses / Technicians } \\
\text { - } & \text { Workers }\end{array}$ & $\begin{array}{c}7(14.3) \\
32(32.0) \\
23(51.1)\end{array}$ & $\begin{array}{l}42(85.7) \\
68(68.0) \\
22(48.9)\end{array}$ & $0.001 *$ \\
\hline Working experience (mean \pm SD): & $14.40 \pm 9.191$ & $8.18 \pm 7.310$ & $0.001 *$ \\
\hline $\begin{array}{l}\text { Exposure to NSSIs: } \mathrm{N}=194 \\
\text { - } \quad \text { Exposed } \\
\text { - } \quad \text { Not exposed }\end{array}$ & $\begin{array}{l}52(31.0) \\
10(38.5)\end{array}$ & $\begin{array}{c}116(69.0) \\
16(61.5)\end{array}$ & 0.445 \\
\hline $\begin{array}{ll}\text { Gloves used at time of injury: } \mathrm{N}=168 \\
\text { - } & \text { Double pair of gloves } \\
\text { - } & \text { Single pair of gloves } \\
\text { - } & \text { No glove } \\
\end{array}$ & $\begin{array}{l}5(17.9) \\
27(32.1) \\
20(35.7)\end{array}$ & $\begin{array}{l}23(82.1) \\
57(67.9) \\
36(64.3)\end{array}$ & 0.235 \\
\hline $\begin{array}{l}\text { Body } \text { Fluid exposure: } \mathrm{N}=194 \\
\text { - } \quad \text { Exposed } \\
\text { - } \quad \text { Not exposed }\end{array}$ & $\begin{array}{l}42(31.8) \\
20(32.3)\end{array}$ & $\begin{array}{l}90(68.2) \\
42(67.7)\end{array}$ & 0.951 \\
\hline $\begin{array}{l}\text { Action after exposure: } \mathrm{N}=132 \\
\text { - Wash with water \& alcohol } \\
\text { - } \quad \text { Did not wash with water \& alcohol }\end{array}$ & $\begin{array}{c}41(33.9) \\
1(9.1)\end{array}$ & $\begin{array}{l}80(66.1) \\
10(90.9)\end{array}$ & 0.092 \\
\hline $\begin{array}{l}\text { Previous jaundice: } \mathrm{N}=194 \\
\text { - } \quad \text { Yes } \\
\text { - } \quad \text { No }\end{array}$ & $\begin{array}{c}5(45.5) \\
57(31.1)\end{array}$ & $\begin{array}{c}6(54.5) \\
126(68.9)\end{array}$ & 0.323 \\
\hline $\begin{array}{l}\text { Partner with HBV or HCV: } \mathrm{N}=194 \\
\text { - } \quad \text { Yes } \\
\text { - } \quad \text { No }\end{array}$ & $\begin{array}{c}2(33.3) \\
60(31.9)\end{array}$ & $\begin{array}{c}4(67.7) \\
128(68.1)\end{array}$ & 0.792 \\
\hline $\begin{array}{l}\text { Previous blood transfusion: } \mathrm{N}=194 \\
\text { - } \quad \text { Yes } \\
\text { - } \quad \text { No }\end{array}$ & $\begin{array}{l}2(22.2) \\
60(32.4)\end{array}$ & $\begin{array}{c}7(77.8) \\
125(67.6)\end{array}$ & 0.521 \\
\hline $\begin{array}{l}\text { Serology of source patient: } \mathrm{N}=77 \\
\text { - } \quad \text { Hepatitis patient } \\
\text { - } \quad \text { Negative } \\
\text { - } \quad \text { Not tested }\end{array}$ & $\begin{array}{l}6(23.1) \\
5(35.7) \\
11(29.7)\end{array}$ & $\begin{array}{l}20(76.9) \\
9(64.3) \\
26(71.3)\end{array}$ & 0.684 \\
\hline $\begin{array}{l}\text { Vaccination ( } \geq \text { 3doses): } \mathrm{N}=194 \\
\text { - } \quad \text { Yes } \\
\text { - } \quad \text { No }\end{array}$ & $\begin{array}{l}16(22.5) \\
36(29.3)\end{array}$ & $\begin{array}{l}55(77.5) \\
87(70.7)\end{array}$ & 0.309 \\
\hline
\end{tabular}

*: Statistically Significant 
Table (5) showed that hepatitis virus infection was significantly associated with older age $(\mathrm{P}<0.001)$, workers as an occupation $(\mathrm{P}=0.001)$ and longer working experience $(\mathrm{P}=0.001)$.

Table (6): Distribution of HCWs included in the study in general surgery department, Assiut University Hospitals, according to demographic characteristics and results of serological investigations, 2013.

\begin{tabular}{|c|c|c|c|c|}
\hline Characteristic & $\begin{array}{l}\text { HBV infection } \\
\text { No. }(\text { R\%) }\end{array}$ & $\begin{array}{c}\text { HCV infection } \\
\text { No. }(\mathbf{R} \%)\end{array}$ & $\begin{array}{c}\text { Total } \\
\text { No. }(\mathrm{C} \%)\end{array}$ & P - Value \\
\hline $\begin{array}{ll}\text { Occupation: } \\
\text { - } & \text { Doctors } \\
\text { - } & \text { Nurses / } \\
& \text { Technicians } \\
\text { - } & \text { Workers }\end{array}$ & $\begin{array}{l}7(100.0) \\
28(87.5) \\
17(73.9)\end{array}$ & $\begin{array}{c}0(0.0) \\
4(12.5) \\
6(26.1)\end{array}$ & $\begin{array}{l}7(11.3) \\
32(51.6) \\
23(37.1)\end{array}$ & 0.187 \\
\hline $\begin{array}{l}\text { Sex: } \\
-\quad \text { Male } \\
-\quad \text { Female }\end{array}$ & $\begin{array}{l}30(83.3) \\
22(84.6)\end{array}$ & $\begin{array}{l}6(16.7) \\
4(15.4)\end{array}$ & $\begin{array}{l}36(58.1) \\
26(41.9)\end{array}$ & $1.000 *$ \\
\hline $\begin{array}{l}\text { Age (in years) } \\
\cdot \quad<40 \\
\cdot \quad \geq 40\end{array}$ & $\begin{array}{l}27(87.1) \\
25(80.6)\end{array}$ & $\begin{array}{l}4(12.9) \\
6(19.4)\end{array}$ & $\begin{array}{l}31(50.0) \\
31(50.0)\end{array}$ & 0.493 \\
\hline $\begin{array}{l}\text { Working experience } \\
-\quad<11 \text { years } \\
-\quad>11 \text { years }\end{array}$ & $\begin{array}{l}20(90.9) \\
32(80.0)\end{array}$ & $\begin{array}{c}2(9.1) \\
8(20.0)\end{array}$ & $\begin{array}{l}22(35.5) \\
40(64.5)\end{array}$ & $0.471 *$ \\
\hline $\begin{array}{l}\text { HB vaccine doses: } \\
\text { - } \quad 0-2 \text { doses } \\
\text { - } \quad \geq 3 \text { doses }\end{array}$ & $\begin{array}{c}36(87.8) \\
(69.2) \\
16(76.2) \\
(30.8)\end{array}$ & $\begin{array}{c}5(12.2) \\
(50.0) \\
5(23.8) \\
(50.0)\end{array}$ & $\begin{array}{l}41(66.1) \\
21(33.9)\end{array}$ & $0.284 *$ \\
\hline $\begin{array}{l}\text { Anti-HBs level: } \\
-\quad<10-100 \mathrm{IU} \\
-\quad>100 \mathrm{IU}\end{array}$ & $\begin{array}{l}25(73.5) \\
(48.1) \\
27(96.4) \\
(51.9)\end{array}$ & $\begin{array}{c}9(26.5) \\
(90.0) \\
1(3.6) \\
(10.0)\end{array}$ & $\begin{array}{l}34(54.8) \\
28(45.2)\end{array}$ & 0.006 \\
\hline Total (R \%) & $52(83.9)$ & $10(16.1)$ & $62(100.0)$ & \\
\hline
\end{tabular}

*Fisher exact test was used.

Table (6) showed that $30.8 \%$ of HBV infected individuals had $\geq 3$ doses of hepatitis $\mathrm{B}$ vaccine compared with $50 \%$ of $\mathrm{HCV}$ infected individuals $(\mathrm{P}=0.284)$. Higher level (> $100 \mathrm{IU}$ ) of anti HBs was significantly higher among HBV infected 
individuals (51.9\%) than HCV infected individuals $(10 \%)(\mathrm{P}=0.006)$.

Our study showed that previously infected individuals had significantly higher level (81.8\%) of Anti HBs than vaccinated individuals $(55.1 \%)(\mathrm{P}=$ 0.009 ).

\section{Discussion}

Hepatitis B and C virus infection among HCWs :

In the present study, among 194 HCWs who were subjected to serological examinations, $5.2 \%$ were Anti-HCV positive, $3.1 \%$ were HBs$\mathrm{Ag}$ positive, $28.9 \%$ were Anti-HBc positive, $55.7 \%$ were Anti-HBs positive and $32.5 \%$ were negative. (Table 2). It is matched with a serologic survey which was conducted for hepatitis B surface antigen (HBsAg) and antibody (antiHBs) in 765 employees at 4 hospitals in Cairo, the reported results were 3\% HBsAg positive and $28 \%$ anti-HBs positive seromarkers (Goldsmith et al., 1989). Another study in Cairo found that, among 597 HCWs who reported a blood exposure, anti-HCV prevalence at screening was $7.2 \%$ (Munier et al., 2013).
In Uganda, the reported results of a study conducted on $311 \mathrm{HCWs}$ were: $36.3 \%$ negative, $3.5 \%$ assumed to be vaccinated, $60.1 \%$ had evidence of previous or current infection and $19.3 \%$ of infected were of indeterminate status (Anti $\mathrm{HBc}+\mathrm{ve}$ ) (Braka et al., 2006). The prevalence of HBV chronic infection in a study in Syria was $2.8 \%$ (Yacoub et al., 2010). In Nigeria among HCWs, HBsAg was positive in $13 \%$ and Anti-HBc was positive in 56\% (Ola, et al. 2012). In Albania, results of a study conducted on HCWS found that, $\mathrm{HBsAg}$, anti-HBc, anti-HCV and anti-HBs prevalence were $8.1 \%, 70 \%$, $0.6 \%$ and $20 \%$, respectively (Kondili et al., 2007).

\section{Exposure to Needle Stick and Sharps Injuries (NSSIs):}

Among $215 \mathrm{HCW}$ in the present study, $86.5 \%$ were exposed to at least one NSSI. (Table 3). During the period of past six months, the reported rates by studies conducted in Egypt (by MOHP) (MOHP, 2004), Ismalia (Egypt) (Khattab et al. ,2008), Syria (Yacoub et al., 2010), and Turkey (Azap et al., 2005) were: $70 \%, 23.9 \%, 76.6 \%$ and $27 \%$ respectively. The reported rates during the period of past 12 months by 
studies conducted in Ethiopia (Kebede and Molla, 2012), Ghana (Brewer, 2004) and Germany (Wicker et al., 2008 ) were, $30,8 \%, 32.4 \%$ and $31.4 \%$ respectively. Portugal study showed that $64.5 \%$ had experienced at least one NSSI in the last 5 years (Martinsa et al., 2012). This difference may be due to the number of HCWs in the facility, different work environment, training, culture and availability of resources (Kebede and Molla, 2012).

In the present study there was no association between infection and exposure to NSSIs and that similar to a study conducted in Georgia (Butsashvili, 2012). This may be due to that Egypt had high prevalence of HBV \& $\mathrm{HCV}$ infection.

The current study found that $26.3 \%$ of the study subjects recapped needles after use ( Table 3), which is an important cause of NSSIs, which was matched with a study conducted in 98 health care facilities in Egypt showed that approximately $36 \%$ of per-cutaneous injuries occur due to two hand recappings (Khattab et al., 2008), 66.6\% in Ethiopia (Kebede and Molla, 2012), 76\% in Syrian study (Yacoub et al., 2010) and 23\% in Georgia (Butsashvili, 2012).
In USA, the Occupational Safety and Health Administration (OSHA) Bloodborne Pathogen Standard prohibits recapping of needles after their use, however, this practice still remains an important source of significant injuries. This may be either due to inadequate training of HCWs or their lack of experience with the correct procedures or lack of access to safety needles that would eliminate the need for recapping. This emphasizes the importance of education, seminars, workshops and safety training program for HCWs to practice precaution behaviors to prevent NSSIs, as recommended by other researchers (Ayranci and Kosgeroglu, 2004). Injuries from hollow-bore needles, especially those used for blood collection or IV catheter insertion are of particular concern. These devices are likely to contain residual blood and are associated with an increased risk for transmission of diseases (CDC, 2008). In the present study, hollow bore and suture needles were responsible for $61.9 \%$ and $33.6 \%$ of NSSIs respectively.

Reporting of injuries to occupational health departments can reduce rates of injury by identifying risk-prone behaviors and practices. 
Under reporting may lead to inaccurate information regarding the overall risk of exposure to pathogens, and full documentation of exposure injuries would guide improvements in prevention (Nagao et al., 2007). On the other hand, an accurate risk assessment can be performed and post exposure prophylaxis provided if necessary (Wilburn and Eijkemans, 2004). In the present study, $95.7 \%$ of injuries were not reported to infection control units (Table 3). This is considered a very high rate compared to other study in Egypt in which $74.7 \%$ didn't report (Talaat et al., 2004), 28.0\% didn't report at Landspítali University hospital (Jelle et al., 2013) and $38.9 \%$ in a study in Portugal (Martinsa et al., 2012).

\section{Exposure to blood or body fluids:}

In the present study $68 \%$ of HCWs were exposed to blood or body fluids (Table 4), nearly similar to a survey conducted in France in 20 hospitals which indicated that $63.3 \%$ had blood or body fluid exposure (Tarantola et al., 2006) but exposure was lower in Portugal in which the exposed HCWs were 33\% (Martinsa et al., 2012) \& $46 \%$ of HCWs were exposed in a study in Georgia (Butsashvili, 2012).
In the present study, there was no association between infection and exposure to blood or body fluids. This may be due to high prevalence $(90.5 \%)$ of hand washing with water and alcohol directly after exposure (Table 4). Another study conducted in Egypt found that $72.6 \% \mathrm{HCW}$ s wash directly after exposure (Munier et al., 2013). Hand hygiene was found to be the simplest, most effective measure for preventing nosocomial infection (Khattab et al., 2008).

To show the effect of hand washing in prevention of infection, a study conducted in Egypt indicated that the use of disinfectant after OBE (Occupational Blood Exposure) was lower among HCWs who developed viremia than among those who did not (6.7\% and $26.3 \%$, respectively; $\mathrm{P}=0.04$ ) (Munier et al., 2013). This is in contrast to a study done in Georgia which found that, there was no significant difference between infection \& exposure to body fluids (Butsashvili, 2012).

\section{Demographic characteristics of healthcare workers (HCWs):}

In the present study, the mean age of infected individuals was significantly higher than non-infected individuals 


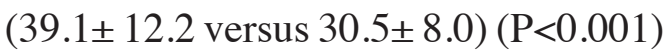
(Table 5). This was matched with a study conducted in Ain shams University Hospitals in Cairo which reported that the proportion of HCV RNA positivity among anti-HCV positive HCWs increased with age (30\% vs. $69.6 \%$, among those $\leq 30$ years and $>30$ years, respectively, $\mathrm{P}=0.01$ ). However for older HCWs, multiple exposures may contribute in the occurrence of infection (Munier et al. 2013). This is in contrast to a study conducted in Albania which reported that, the highest (11.4\%) HBsAg prevalence was observed in the youngest age group (20-30 years of age) (Kondili et al. 2007).

Regarding sex, there was no statistical significant difference between sex \& infection $(\mathrm{P}=0.718)$ (Table 5). This was matched with $\mathrm{HCV}$ viremia in Ain Shams University Hospitals in Cairo that indicated the cumulative incidence of transient viremia was not significantly different between men and women (Munier et al., 2013). In contrast to a study conducted in Georgia, HCV infection status was significantly associated with occupation and gender, as male HCWs were 2.7 times as likely to be infected with $\mathrm{HCV}$ as compared with nursing females. A similar finding was reported by another study in Egypt, where sero-positivity of HBV by sex was greater for males ( $\mathrm{P}$ $<0.01$ ) (Goldsmith et al., 1989).

Regarding occupation, workers had the highest frequency of infection $(51.1 \%)$, followed by nurses and technicians (32\%) and lastly physicians (14.3\%), $(\mathrm{P}=0.001)$ (Table 5). This is consistent with a study conducted in Egypt which found that combined HBsAg and anti-HBs frequencies by occupational group were: nonprofessional staff $(60 \%)$, graduated nurses (33\%) and physicians (29\%) (Goldsmith et al., 1989). In a study conducted in Uganda, it was found that nurse staff had high frequency of HBsAg \& Anti-HBc followed by doctors (Braka et al., 2006), in contrast to a study in Nigeria which found that HBV infection was similar in all the different occupational groups of HCWs (Ola et al., 2012).

Regarding working experience, infected individuals had significantly longer working experiences (14.4 \pm 9.1 years) than non infected individuals $(8.2 \pm 7.3)(\mathrm{P}=0.001)$ ( Table 5), this may be attributed to long incubation 
period of $\mathrm{HCV}$ so disease appear late or may be with more frequent exposure develop more risk of infection. A study in Ethiopia showed that participants with working experience of more than 10 years had higher rate of NSSIs (which may help in transmission of infection) compared with those having less than 5 years of experience(WHO, 2009).

\section{Hepatitis B vaccination among HCWs:}

Hepatitis B vaccine is $95 \%$ effective in preventing $\mathrm{HBV}$ infection and its chronic consequences (WHO, 2000). In the present study, we found that $61.4 \%$ received $\mathrm{HBV}$ vaccine and only $38.1 \%$ of HCWs completed three doses of $\mathrm{HB}$ vaccine.

Varying figures were reported from different countries of the world regarding complete vaccination ( $\geq 3$ doses) against hepatitis B virus among HCWs, ranging from 68\% in Turkey (Azap et al., 2005), $61.5 \%$ in India (Setia et al., 2013), $56.1 \%$ in Syria (Yacoub et al., 2010), $41.2 \%$ in Germany (Schenkel et al., 2008) to $37.9 \%$ in Nigeria (Sofola et al., 2007).
In our study there is no association between hepatitis B vaccination (3 doses or more) and development of hepatitis virus infection (Table 5). On the other hand, $14(16.9 \%)$ didn't receive any dose of vaccine but have Anti-HBs level exceeded $100 \mathrm{IU} / \mathrm{L}$, this may be present due to previous infection. A similar finding was reported by a study in Syria where 31 (16.5\%) HCWs had never been vaccinated and have detectable anti-HBs titers, positive antiHBc antibodies (Yacoub et al., 2010).

In the present study, there was no association between vaccination $\&$ infection, this may be due to that Anti-HBs level was insufficient as shown before. Out of $52 \mathrm{HBV}$ infected individuals, $16(30.8 \%)$ received $\geq 3$ doses of HB vaccine (Table 6). This may indicate that HCWs may need more booster doses as they are in higher risk than other population \& they recommended to make Anti-HBs level after vaccination to ensure that it give good response. Also infection may be present before vaccine administration.

\section{Conclusion and Recommendations}

Based on the results of the present study, we can conclude that: 
- The frequency of hepatitis B and C virus infection among health care workers (HCWs) in general surgery department, Assiut University Hospitals is high,

- Hepatitis B vaccination among HCWs is low,

- Exposure to NSSIs, blood and body fluids of the patients is high and

- Reporting of NSSIs to Infection Control Unit is low.

\section{Therefore, we recommend:}

- Make serological profile for every $\mathrm{HCW}$ for $\mathrm{HBV} \& \mathrm{HCV}$ before employment, and regular check up every 6 months,

- Total coverage of all susceptible HCWs by hepatitis B vaccine ( $\geq$ 3doses) and to detect Anti HBs level after vaccination by 4 months,

- Avoid NSSIs and exposure to blood and body fluids of the patients,

- Reporting system should be encouraged and improved. Availability of safety needles, protective equipments (e.g. gloves), seminars, education, workshops and safety training programs for HCWs play an important role in the accomplishment of these recommendations.

\section{Conflict of interests}

Authors have declared that no conflict of interests exists.

\section{References}

1. Alter M J, and Mast EE (1994): The epidemiology of viral hepatitis in the United States. Gastroenterol Clin N Am; 23:437-455.

2. Ayranci U and Kosgeroglu N (2004): Needle sticks and sharps injuries among nurses in the health care sector in a city of western Turkey. $\mathrm{J}$ Hosp Infect; 58:216-223.

3. Azap A, Ergönül O, Memikoglu KO, Yesilkaya A, Altunsoy A and Bozkurt GY (2005): Occupational exposure to blood and body fluids among healthcare workers in Ankara, Turkey. Am J Infect Control ; 33:48-52

4. Braka F, Nanyunja M, Makumbib I, Mbabazi W, Kasasa S, and Lewis RF (2006): Hepatitis $\mathrm{B}$ infection among health workers in Uganda: Evidence of the need for health worker protection. Vaccine; 24:6930-6937.

5. Brewer T (2004): Planning for the 12th ICID in Lisbon. ISID News 8 (2):1-7.

6. Butsashvili M, Kamkamidze G, Kajaia M, Morse DL, Triner W and DeHovitz J (2012): Occupational exposure to body fluids among health care workers in Georgia. Occup Med (Lond) ;62(8): 620-626.

7. CDC (2008): Workbook for designing, implementing, \& evaluating sharps injury prevention ; 1-161.

8. Ciesielski CA and Metler, RP (2003): Occupationally acquired human immunodeficiency virus (HIV) infection: national case surveillance data during 20 years of the HIV epidemic in the United States. Infection Control Hospital Epidemiol Rev; 24:86-96. 
9. Da Villa G and Sepe A (1999): Immunization programme against hepatitis B virus infection in Italy: cost-effectiveness. . Vaccine; 17: 17341738.

10. Goldsmith RS,Zakaria S, Zakaria MS, Mabrouk MA, Hanafy AM, Kaliouby AH, \& el-Rifae M (1989): Occupational exposure to hepatitis B virus in hospital personnel in Cairo, Egypt. ActaTropica ; 46(5-6):283-290.

11. Gutmann L, Carpentier AF, BélecL, KuoY, Fabiani J, Mohamed AS and Lévy M (1999): Decreasing occupational risk related to bloodborne viruses in cardiovascular surgery in Paris, France. Ann ThoracSurg ; 68 : 2267-2272.

12. Jelle AE, Hafsteinsdottir EJ, Gudlaugsson O and Kristjansson M (2013): Epidemiology of needle sticks at Landspítali University Hospital during the years 1986-2011. Laeknabladid; 99(12):559-564.

13. Kebede G and Molla M (2012): Needle sticks and sharps injuries among health care workers in Gondar city, Ethiopia. Safety Science; 50: 1093-1097.

14. Khattab M, EL-Hadedy G, Al-Gammal H and Bendary M (2008): Assessment of hand hygiene and sharp disposal practice in family medicine centers belonging to Suez Canal University in Ismailia governorate. Thesis (M.Sc) - SCU.F. of med. dep. of F.M., 614(44):1-112

15. Kondili LA, Ulqinaku D, Hajdini M, Basho M, Chionne P, Madonna E and Rapicetta M (2007): Hepatitis B virus infection in health care workers in Albania: a country still highly endemic for HBV infection. Infection Control and Hospital Epidemiology; 35(2):94-97

16. Lauer G and Walker B (2001): Hepatitis C virus infection. The New England Journal of Medicine; 345(1):41-52.

17. Lavanchy $\mathrm{D}$, Interlifescience and Ticino $\mathrm{M}$ (2011): Evolving epidemiology of hepatitis C virus. Clin Microbiol Infect; 17:107-115.

18. Martinsa A, Coelhob AC, Vieiraa M, Matosc M and Pintob ML (2012): Age and years in practice as factors associated with needlestick and sharps injuries among health care workers in a Portuguese hospital. Accident Analysis and Prevention; 47:11- 15.

19. MOHP (2004): The national guideline for infection control, Egypt: Ministry of Health and Population (accessed at: www. drguide. mohp.gov.eg/ New Site/ E-learning /Infection Control/ infetrlp1.asp

20. Munier A, Marzouk D, Abravanel F, El-Daly M and Taylor S (2013): Frequent Transient Hepatitis C viremia without Sero conversion among Healthcare Workers in Cairo, Egypt. PLoS ONE; 8(2):e57835.

21. Nagao Y,Baba H, Torii K, Nagao M,Hatakeyama $\mathrm{K}$, Iinuma $\mathrm{Y}$, Ichiyama S, Shimokata $\mathrm{K}$ and Ohta M (2007): A long-term study of sharps injuries among health care workers in Japan. Am J Infect Control; 35:407-411.

22. Ola SO, Odaibo GN, Olaleye OD and Ayoola EA (2012): Hepatitis B and E viral infections among Nigerian healthcare workers. Afr J Med Med Sci; 41(4):387-391.

23. Schenkel K, Radun D, Bremer V, Bocter N and Hamouda O (2008): Viral hepatitis in Germany: Poor vaccination coverage and little knowledge about transmission in target groups. BMC Public Health; 8:132.

24. Setia S, Gambhir R., Kapoor V, Jindal G, Garg S and Setia S (2013): Attitudes and Awareness Regarding Hepatitis B and Hepatitis C Amongst Health-care Workers of a Tertiary Hospital in India. Ann Med Health Sci Res; 3(4): 551-558.

25. Sofola OO, Folayan MO, Denloye OO and Okeigbemen SA (2007): Occupational exposure to blood borne pathogens and management of exposure incidents in Nigerian dental schools. J Dent Educ; 71: 832-837.

26. Talaat M, Kandeel A, El-Shoubary W, Bodenschatz C, Khairy I, Oun S and Mahoney FJ (2004): Occupational exposure to needle stick injuries and hepatitis $B$ vaccination coverage among health care workers in Egypt. American Journal of Infection Control, 31(8): 469-474. 
27. Tarantola A, Golliot F and L'Heriteau F (2006): Assessment of preventive measures for accidental blood exposure in operating theaters: A survey of 20 hospitals in Northern France. Am J Infect Control; 34: 376-82.

28. Varghese MG, Abraham, CO and Mathai D (2003): Post-exposure prophylaxis for blood borne viral infections in healthcare workers. Postgrad Med J; 79: 324-328.

29. WHO (2000): Hepatitis B. Geneva. [Cited 2012 Dec 12]. Fact sheet [monograph on the internet] Available from: http://www.who. intmediacentre/factsheet/fs204/en

30. WHO (2003): Aide-Memoire for a strategy to protect health workers from infection with blood borne viruses. Department of Blood Safety and Clinical Technology, Geneva,Switzerland. http://www.who.int/injection_safety/toolbox/ en/AM_HCW_Safety_EN.pdf 22.11.11).
31. WHO (2009): Regional Committee for the Eastern Mediterranean: The growing threats of hepatitis $\mathrm{B}$ and $\mathrm{C}$ in the Eastern Mediterranean Region: a call for action. 56th Session.

32. Wicker S, Jung J and Allwinn R (2008): Prevalence and prevention of needle stick injuries among health care workers in a German university hospital. Int. Arch. Occup. Environ Health; 81:347-354.

33. Wilburn S and Eijkemans G (2004): Preventing needle stick injuries among health care workers: WHO-ICN collaboration. Int J Occup Environ Health; 10:451-456.

34. Yacoub R, Ali RA, Moukeh G, Lahdo A, Mouhammad Y and Nasser M (2010): Hepatitis $B$ vaccination status and needle stick injuries among healthcare workers in Syria. J Glob Infect Dis; 2(1): 28-34. 